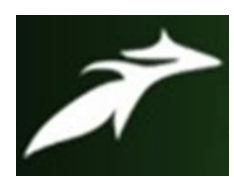

Alice Kaintura et al, International Journal of Advances in Agricultural Science \& Technology,

Vol.8 Issue.11, November-2021, pg. 70-76

\title{
Effect of Organic Manures on the Growth and Yield Attributes of Spinach Beet (Beta vulgaris var bengalensis) at Low Hills of Uttarakhand
}

\author{
Alice Kaintura $^{1^{*}}$; Dr. Suneeta Singh ${ }^{2}$; Dr. Anil Kumar Saxena ${ }^{3}$ \\ ${ }^{1 *}$ Research Scholar, Department of Horticulture, School of Agricultural Sciences, SGRR University, \\ Dehradun- 248 001, Uttarakhand, INDIA \\ ${ }^{2}$ Assistant Professor \& Head, Department of Horticulture, School of Agricultural Sciences, SGRR \\ University, Dehradun- 248 001, Uttarakhand, INDIA \\ ${ }^{3}$ Professor \& Head, Department of Soil Science, School of Agricultural Sciences, SGRR University, \\ Dehradun- 248 001, Uttarakhand, INDIA \\ *Corresponding Author Email: kainturalice98@ gmail.com \\ DOI: 10.47856/ijaast.2021.v08i11.008
}

\begin{abstract}
A field experiment was planned and conducted during 2020-21 at Horticulture Research Block, Department of Horticulture, School of Agricultural Sciences, SGRR University, Dehradun, Uttarakhand to investigate the "Effect of different organic manures on the growth and yield attributes of spinach beet at lower hills of Uttarakhand". The experiment was laid out in randomized block design with three replications and nine treatments including various organic manures at different concentrations. Observations on various growth and yield attributes were recorded at regular intervals. Studies on vegetative and yield attributes were recorded using standard method of measurements. Among all the organic treatments, soil application with Farmyard manure $(5 \mathrm{~kg})+$ Vermicompost $(2.5 \mathrm{~kg})+$ foliar spray of Vermiwash $(25 \%)$ was sown the significant improvement in plant height $(\mathbf{c m})$, number of leaves per plants, length of leaves $(\mathrm{cm})$, width of leaves $(\mathrm{cm})$, petiole length $(\mathrm{cm})$, root length $(\mathrm{cm})$ and yield than other treatments.
\end{abstract}

Keywords: Spinach, organic manures, FYM, vermicompost, vermiwash

\section{Introduction}

Among different vegetable crops, leafy vegetables are quite high in their protective food value. They are important because oftheir successful and relatively easy cultivationas well as their high nutritive value, at acomparatively low cost. Palak or spinach beet (Beta vulgaris var. bengalensis; $2 \mathrm{n}=2 \mathrm{x}=18$ ), commonly known as 'Indian spinach' in English and 'Palak' in Hindi, originated from Indo-Chinese region (Nath, 1976) belongs to the genus Beta, species vulgaris and family chenopodiaceae. Leaves of this might have been first used in Bengal and hence known as var. bengalensis. It is also called as Beetleaf and Desi palak. It is closely 


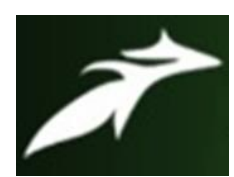

Alice Kaintura et al, International Journal of Advances in Agricultural Science \& Technology, Vol.8 Issue.11, November-2021, pg. 70-76

ISSN: 2348-1358

Impact Factor: 6.057

NAAS Rating: 3.77

related to beet root, sugar beet and Swiss chard. Sea beet (Beta vulgaris var. maritima) is the ancestor of palak. Its tender soft succulent leaves are used as vegetable. Being the cheapest source of calcium, iron and phosphorus, it is valued much for its tender leaves. The continuous use of chemical fertilizers and pesticides in the cultivation of horticulture crops have caused decreased soil fertility physical and chemical properties of soil. Organics play a vital role inrestoring the soil fertility and stabilizing crop productivity. Therefore, the application of plant nutrients through organic sources like FYM, vermicompost, biofertilizer along with different foliar spray remains the alternate choice for maintaining sustainable production. It is rich in minerals and hence called as "Mines of Minerals" and cheap source of iron, Vitamin A 9770 IU, calcium 380 mg/100g, Vitamin C 70 mg/100g (Muthu Kumar and Selvakumar, 2017), protein, vitamin K, Vitamin E, vitamin D, folic acid, thiamine, riboflavin, nicotinic acid, pyridoxine, antioxidants as carotene, flavones, indoles and Isothiocyanates, essential amino acid etc. (Singh, 2001). Palak is a leaf crop, leaf yield is governed by several factors viz, fertility of soil, application of nitrogen during cropping period, availability of soil moisture, climatic conditions, type and kind variety grown and management practices. However, under favourable growing conditions, about 80 to 100 quintals of marketable leaves are obtained from one hectare. Varieties of broad leaved are usually high yielding than those of short leaves. Palak is highly perishable vegetable. The quality of leaves deteriorates with the increase of time after harvesting.

\section{Material and Methods}

The experiment was conducted at Horticulture Research Block, Department of Horticulture, School of Agricultural Sciences, Shri Guru Ram Rai University, Pathri Bagh, Dehradun, Uttarakhand, India during the rabi season 2020-21 to study the "Effect of organic manures on the growth and yield attributes of spinach beet (Beta vulgaris var bengalensis) at low hills of Uttarakhand". The experiment was laid out in randomized block design with three replications and nine treatments including various organic manures at different concentrations. The treatment details are as below:

Table 1: Treatment combinations

\begin{tabular}{|c|c|c|}
\hline Number of Treatment & Combinations & Concentration \\
\hline $\mathrm{T}_{1}$ & Control & $0 \%$ \\
\hline $\mathrm{T}_{2}$ & Farmyard Manure & $10 \mathrm{Kg} / \mathrm{plot}$ \\
\hline $\mathrm{T}_{3}$ & Vermicompost & $5.0 \mathrm{Kg} / \mathrm{plot}$ \\
\hline $\mathrm{T}_{4}$ & Vermiwash & $50 \%$ \\
\hline $\mathrm{T}_{5}$ & $\mathrm{FYM}+$ Vermicompost & $5.0 \mathrm{Kg}+2.5 \mathrm{Kg}$ \\
\hline $\mathrm{T}_{6}$ & $\mathrm{FYM}+$ Vermiwash & $5.0 \mathrm{Kg}+50 \%$ \\
\hline $\mathrm{T}_{7}$ & Vermicompost + Vermiwash & $2.5 \mathrm{Kg}+50 \%$ \\
\hline $\mathrm{T}_{8}$ & $\mathrm{FYM}+$ Vermicompost + Vermiwash & $10.0 \mathrm{Kg}+5.0 \mathrm{Kg}+50 \%$ \\
\hline $\mathrm{T}_{9}$ & $\mathrm{FYM}+$ Vermicompost + Vermiwash & $5.0 \mathrm{Kg}+2.5 \mathrm{Kg}+25 \%$ \\
\hline
\end{tabular}




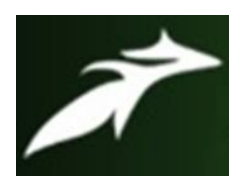

Alice Kaintura et al, International Journal of Advances in Agricultural Science \& Technology, Vol.8 Issue.11, November-2021, pg. 70-76

ISSN: 2348-1358

Impact Factor: 6.057

NAAS Rating: 3.77

The variety "Ever Green" was used as the test crop. As per the treatment vermicompost and farmyard manure were applied as soil basal application and the vermiwash is applied as foliar spray. The growth observations were recorded on plant height $(\mathrm{cm})$, number of leaves per plant, leaf length $(\mathrm{cm})$, width of leaf $(\mathrm{cm})$, petiole length $(\mathrm{cm})$, root length $(\mathrm{cm})$, fresh weight (g) and dry weight of plant $(\mathrm{g})$. The plant height was measured from ground level to the tip of longest leaf at 20,30,40,50, and 60 days after sowing from randomly three plants and their mean was worked out. Total number of leaves counted for three randomly selected plants and counted at 20, 30, 40, 50 and 60 days after sowing and their mean was worked out and same as done for other parameters.

\section{Results and Discussion}

The findings of the present study as well as relevantdiscussion have been summarized under following headings:

\section{Plant Height}

The organic treatments of soil application with FYM @ 5.0Kg + VC @ 2.5\% + foliar spray of vermiwash $(25 \%)\left(\mathrm{T}_{9}\right)$ recorded significantly highest crop plant height of $9.83 \mathrm{~cm}$ on 60DAS. This might be due to the presence of large amount of humic substances in the vermicompost which might have improved the soil properties and increased the microbial activity of the soil and resulted in the release of nutrients. This is found to be in accordance with the findings of Ansari (2008) who stated that organic amendments like vermicompost and vermiwash promote humification, increased microbial activity and enzyme production, which, in turn, bring about the aggregate stability of soil particles, resulting in better aeration and they also has a property of binding mineral particles like calcium, magnesium and potassium in the form of colloids of humus and clay, facilitating stable aggregates of soil particles for desired porosity to sustain plant growth.

\section{Number of Leaves per Plant}

The organic treatments of soil application with FYM @ 5.0Kg + VC @ 2.5\% + foliar spray of vermiwash $(25 \%)\left(\mathrm{T}_{9}\right)$ recorded significantly highest crop plant height of 13.9 on 60 DAS which was found at par with $\mathrm{T}_{2}(11.53)$ and the minimum number of leaves were reported at 20 DAS. Leaf number increased with response to cutting and with plant height and this could bedue to availability of nutrients in higher level along withgrowth substances throughout crop growth period. Increase in leaf number was reported in palak (Jha and Jana, 2009). Minimum number of leaves in third cutting might be due to increased leaf area.

\section{Leaf Length}

Among the different treatments, soil application with FYM @ 5.0Kg + VC @ 2.5\% + foliar spray of vermiwash $(25 \%)\left(\mathrm{T}_{9}\right)$ recorded the highest leaf length of $2.53 \mathrm{~cm}$ while lowest leaf length recorded in $\mathrm{T}_{6}(1.57 \mathrm{~cm})$. This might be due to the increased uptake of available major nutrients of the plant which results in the translocation of nutrients to the plant part. This is in accordance with the findings of Jadhav (2014) who reported that vermicompost influence 


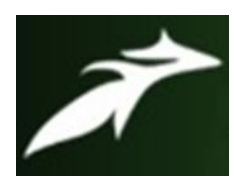

Alice Kaintura et al, International Journal of Advances in Agricultural Science \& Technology, Vol.8 Issue.11, November-2021, pg. 70-76

ISSN: 2348-1358

Impact Factor: 6.057

NAAS Rating: 3.77

plant growth directly via the supply of plant growth regulating substances (PGR) which results in the uptake of nutrients.

\section{Leaf Width}

The highest leaf width was recorded in the organic treatment T9 (FYM @ 5.0Kg + VC @ $2.5 \%$ + foliar spray of vermiwash $(25 \%)$ ) which was found to be on par with treatment T2 (FYM @ 10Kg/plot). This might be due to the continuous nutrient availability by the use of organics. This is found to be in accordance with findings of Hasan and Solaiman (2013) who reported that the use of organics in cauliflower results in the continuous availability of nutrients to the plants and increased the growth and development.

\section{Petiole Length}

The organic treatments of soil application with FYM @ 5.0Kg + VC @ 2.5\% + foliar spray of vermiwash $(25 \%)$ (T9) recorded significantly highest crop petiole length of $1.94 \mathrm{~cm}$ on 60DAS which was found at par with T8 $(1.8 \mathrm{~cm})$. The lowest petiole length was recorded in T5 (FYM @ 5.0Kg + VC @ 2.5Kg).

\section{Root Length}

The root length was significantly affected by the application of FYM, vermicompost and vermiwash at different stages of plant growth. The highest root length of $7.21 \mathrm{~cm}$ was recorded in T9 with FYM @ 5.0Kg + VC @ 2.5\% + foliar spray of vermiwash (25\%) was at par with $\mathrm{T} 8(6.53 \mathrm{~cm})$. The lowest root length was recorded at 20DAS.

\section{Yield Parameters}

Among the various organic treatments, the soil application with FYM $(5.0 \mathrm{~kg})+\mathrm{VC}(2.5 \mathrm{~kg})+$ foliar spray of VW (25\%) resulted in increased fresh weight of leaves per plant $(1.88 \mathrm{~g})$, dry weight of plant $(0.66 \mathrm{~g})$, yield per plot $(4 \mathrm{~kg} / \mathrm{plot})$ and yield per hectare $(1176.0 \mathrm{~kg} / \mathrm{ha})$. The increase in yield attributes might be due to the application of organic source of fertilizers viz., FYM, vermicompost and vermiwash which increases the plant height, number of leaves per plant, leaf length, dry matter production. Ansari (2007) observed that better growth of plants and higher yield in onion by slow release of nutrients for absorption with additional nutrients like gibberellin, cytokinin and auxins, by the application of organic inputs like vermicompost in combination with vermiwash. 


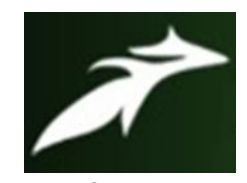

Alice Kaintura et al, International Journal of Advances in Agricultural Science \& Technology,

Vol.8 Issue.11, November-2021, pg. 70-76

Table 2: Effect of different organic manures in Plant height, Number of leaves, Leaf length and Leaf width

\begin{tabular}{|c|c|c|c|c|}
\hline Treatments & Plant height (cm) & Number of leaves & Leaf length $(\mathrm{cm})$ & Leaf width $(\mathrm{cm})$ \\
\hline $\mathrm{T}_{1}$ & 4.19 & 6.85 & 1.63 & 0.65 \\
\hline $\mathrm{T}_{2}$ & 3.73 & 6.39 & 1.73 & 0.87 \\
\hline $\mathrm{T}_{3}$ & 3.25 & 5.56 & 1.54 & 0.7 \\
\hline $\mathrm{T}_{4}$ & 4.00 & 5.99 & 1.70 & 0.78 \\
\hline $\mathrm{T}_{5}$ & 3.57 & 6.49 & 1.45 & 0.73 \\
\hline $\mathrm{T}_{6}$ & 3.75 & 6.72 & 1.45 & 0.65 \\
\hline $\mathrm{T}_{7}$ & 3.44 & 6.01 & 1.50 & 0.67 \\
\hline $\mathrm{T}_{8}$ & 4.4 & 6.56 & 1.75 & 0.69 \\
\hline $\mathrm{T}_{9}$ & 6.23 & 8.01 & 2.21 & 1.03 \\
\hline $\mathrm{CD}_{(5 \%)}$ & 1.92 & 1.90 & 1.56 & 0.26 \\
\hline SE(d) & 0.35 & 0.99 & 0.27 & 0.08 \\
\hline SE (m) & 0.42 & 0.81 & 0.22 & 0.06 \\
\hline C.V. (\%) & 3.52 & 3.37 & 2.32 & 1.86 \\
\hline
\end{tabular}




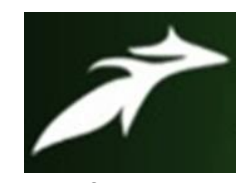

Alice Kaintura et al, International Journal of Advances in Agricultural Science \& Technology,

Vol.8 Issue.11, November-2021, pg. 70-76

Table 3: Effect of different organic manures in Petiole length (cm), Root length, Fresh weight, Dry weight

\begin{tabular}{|c|c|c|c|c|}
\hline Treatments & Petiole length $(\mathrm{cm})$ & Root length $(\mathrm{cm})$ & Fresh weight (g) & Dry weight (g) \\
\hline $\mathbf{T}_{1}$ & 1.20 & 3.16 & 0.61 & 0.22 \\
\hline $\mathbf{T}_{2}$ & 1.08 & 3.88 & 0.60 & 0.22 \\
\hline $\mathbf{T}_{3}$ & 1.04 & 3.41 & 0.27 & 0.23 \\
\hline $\mathbf{T}_{4}$ & 1.1 & 3.58 & 0.35 & 0.28 \\
\hline $\mathbf{T}_{5}$ & 0.92 & 3.54 & 0.36 & 0.27 \\
\hline $\mathbf{T}_{6}$ & 1.05 & 3.44 & 0.33 & 0.29 \\
\hline $\mathbf{T}_{7}$ & 1.07 & 3.19 & 0.32 & 0.21 \\
\hline $\mathbf{T}_{8}$ & 1.15 & 3.94 & 0.45 & 0.23 \\
\hline $\mathbf{T}_{9}$ & 1.51 & 4.38 & 1.05 & 0.45 \\
\hline $\mathrm{CD}_{(5 \%)}$ & 1.16 & 1.18 & 1.02 & 0.06 \\
\hline SE(d) & 0.17 & 0.50 & 0.08 & 0.03 \\
\hline $\mathrm{SE}(\mathrm{m})$ & 0.14 & 0.40 & 0.07 & 0.03 \\
\hline C.V. (\%) & 1.09 & 3.64 & 2.35 & 1.36 \\
\hline
\end{tabular}




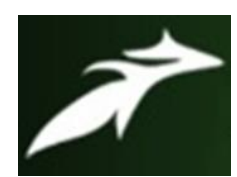

Alice Kaintura et al, International Journal of Advances in Agricultural Science \& Technology, Vol.8 Issue.11, November-2021, pg. 70-76

ISSN: 2348-1358

Impact Factor: 6.057

NAAS Rating: 3.77

\section{Conclusion}

On the basis of present investigation on effect of organic manures on the growth and yield of spinach beet cv. Evergreen it can be concluded that different organic manures with combination of FYM $(5.0 \mathrm{~kg})+\mathrm{VC}(2.5 \mathrm{~kg})+\mathrm{VW}(25 \%)$ found to be most effective in treatment for increasing plant height, number of leaves/plants, petiole length, leaf width, leaf length, root length, fresh and dry weight, leaf yield per plot and yield q/ha. After that combination of organic manures with FYM $(10.0 \mathrm{~kg})+\mathrm{VC}(5.0 \mathrm{~kg})+\mathrm{VW}(50 \%)$ also found to be effective. Although in many parameters' treatment T6 i.e., FYM (5.0kg) + VW (50\%) found to be remained at par at 20DAS, 30DAS, 40DAS, 50DAS and 60DAS or it found to be profitable as compared to rest of treatments.

\section{References}

[1]. Abdul A.A. 2008. Effect of vermicompost and vermiwash on the productivity of spinach (Spinacia oleracea), onion (Allium cepa) and potato (Solanum tuberosum). World J. Agric. Sci., 4(5): 554-557.

[2]. Ansari A. A. and Sukhraj K. Effect of vermiwash and vermicompost on soil parameters and productivity of okra (Abelmoschus esculentus) in Guyana. African Journal of Agricultural Research. 2010; 5(14):1794-1798.

[3]. Buckerfield, J.C., T. Flavel, K.E. Lee and K.A. Webster, 1999.Vermicomposts in solid and liquid form as plant-growth promoter. Pedobiologia.43: 753-759.

[4]. Bharad, S. G., Korde, S. D., Satpute, P. and Baviskar, M.N. 2013. Effect of organic manure and number on growth yield and quality of Indian spinach. Asian J. Hort., 8 (1): 60-64.

[5]. Dadiga, A., Kadwey, S. and Parjapati, S. 2015. Influences of organic and inorganic source of nutrients ongrowth, yield attributed traits and yield economic of coriander (Coriandrum sativum L.) CVJD-1. J. Agri. Res., 46 (6): 577-80.

[6]. D. Rajesh and Ahmed Abdul Haleem Khan. 2019. Preparations of vermiwash its effects on plantgrowth and development of red spinach (Amaranthus dubius mart. ex thell.). World Journal of Pharmaceutical Research.

[7]. J. Singh. Soil fertility management. Basic Horticulture. 2002. Kalyani publishers. 2018. 233-248.

[8]. J, Sharma and A. Sunita. 2014. Impact of organic fertilizers on growth, yield and quality of spinach. Indian J. Plnt Sci, 3 (3): 37-43.

[9]. Jha M. K and Jana J.C. Evaluation of vermi compost and farm yard manure in nutrient management of spinach (Beta vulgaris var. bengalensis). Indian Journal of Agricultural Sciences. 2009, 79(7).

[10].Jadhav, P, D. J. Patel, A. Kireeti, N. B Patil, S. S Dekhane, and N. B. Harad. 2014. Effect of different levels of vermicompost on growth and yield of radish cv. local variety. International J. Information Research and Review, 1(2): $29-31$.

[11].M. S. Fageria, B. R. Choudhary and R. S. Dhaka. Vegetable Crops Production Technology. 2003. Kalyani publishers. 2019. Vol II. Pg. no. 222-225. 